\title{
GeoGuides, urban geotourism offer powered by mobile application technology
}

\begin{abstract}
Scientific research about geological and geomorphological heritage recently proved to be the base of new opportunities for tourism. The peculiar case of urban landscape analysis offers new frontiers to the traditional urban cultural tourism. The tourism offer based on natural aspects of urban areas is described in this paper thanks to three examples of urban geotourism tools: GeoGuide Lausanne, TOURinStones and GeoGuide Rome mobile applications. Each case focuses on the transfer of geoscientific knowledge from scientific research to the "tourist" content, with the innovative support of the mobile application technology. The apps contribute to the promotion of the links between cultural and geological heritage, which is the goal of urban geotourism: to convey the message that substrate profoundly influences the culture that is established on it. The mobile application technology has many strengths for interpretation, e.g. by overlaying images or adding sounds and videos, which allow the visitors to discover landforms now covered by buildings and infrastructures; it has also technical strengths, such as looking for additional information and organizing the city visit at home or to re-experience it after the trip. The apps do not have any impact on the field, they are concise, easy to read, interactive and funny. The public understanding of science is very important, it helps enhancing the role of the researchers and the impact of their work on the society and the daily lives of citizens. In this context GeoGuide apps are useful to transfer knowledge and make it usable to people.
\end{abstract}

Keywords geoheritage, urban geotourism, tourist guide, mobile application, knowledge transfer tool, urban landscapes.

Alessia Pica ${ }^{a}$, alessia.pica@uniroma1.it, +393886241773 (corresponding author) ID 0000-0003-2877-1619

Emmanuel Reynard ${ }^{b}$, emmanuel.Reynard@unil.ch ID 0000-0001-5980-9902

Lucien Grangier ${ }^{b}$, lucien.grangier@unil.ch ID 0000-0002-1219-8021

Christian Kaiser ${ }^{b}$, christian.kaiser@unil.ch ID 0000-0002-3482-170X

Luca Ghiraldi ${ }^{c}$, luca.ghiraldi@regione.piemonte.it

Luigi Perotti ${ }^{d}$, luigi.perotti@unito.it

Maurizio Del Monte ${ }^{a}$ maurizio.delmonte@uniroma1.it ID 0000-0002-9564-3548

${ }^{a}$ Earth Sciences Department, Sapienza University of Rome, P.zzle A. Moro 5, I-00185 Rome, Italy

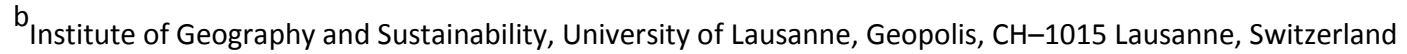

${ }^{c}$ Natural Sciences Museum of Turin, Via Giolitti 36, 10123 Turin, Italy

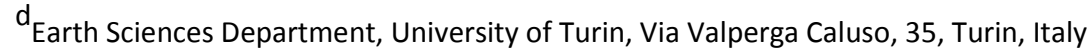




\section{INTRODUCTION}

Geoheritage studies have been highly intensified and diversified in recent years (e.g. Gray 2004; Brilha 2005; Reynard et al. 2009; Reynard and Coratza 2013; Brilha 2016). This field of research has a strong applicability, especially in interdisciplinary and sustainable forms of tourism, namely geotourism (Hose 2000, 2012; Dowling and Newsome 2006). For this purpose the most modern technologies are used for supporting the dissemination of research results, in particular for educational purposes (Cayla 2014 and references therein). Popular technologies are the electronic mobile applications that have been fast developing for tourism purposes (Kenteris et al. 2011a and references therein). This is the case of smartphone and tablet applications developed by the Institute of Geography and Sustainability of Lausanne University (IGD), devoted to geotourist itineraries (Reynard et al. 2015).

This work presents three applications using the same technology and focused on urban geotourism. These are the GeoGuide Lausanne (Reynard et al. 2015) - a virtual itinerary showing the relationships between geology/geomorphology, climate/hydrology, and urban development in Lausanne (Switzerland) -, TOURinSTONES - a virtual guide on the rocks used for the construction of urban monuments and infrastructures in the city of Turin (Italy) -, and GeoGuide Rome - a geotourist itinerary (Pica et al., 2016a) based on the Aeterna Urbs millenarian historical development, an example of cultural aspects deeply related to morphological features (Pica et al. 2016b). In each case, the focus is put on the transfer of geoscientific knowledge from scientific research to the "tourist" content, with the technical constraints of the application.

\section{GEOTOURISM, INTERPRETATION AND MOBILE APPLICATIONS}

Geotourism is a form of tourism at the interface between cultural tourism and ecotourism (Pralong 2006a) that "sustains and enhances the identity of a territory, taking into consideration its geology, environment, culture, aesthetics, heritage and the well-being of its residents. Geological tourism is one of the multiple components of geotourism" (Arouca Declaration 2011). In particular, it proposes to the tourists a set of activities, products, services and infrastructures that aim at the promotion of Earth sciences (Hose 1996, 2000, 2012; Dowling and Newsome 2006). One of the aims of geotourism is therefore the dissemination of knowledge about geoheritage, i.e. geosites (e.g. Wimbledon 2011; Brilha 2016) and geomorphosites (Panizza 2001; Reynard et al. 2009; Reynard and Coratza 2013), which form the in-situ geoheritage, as well as collections of geological objects (minerals, fossils), which are part of the so-called ex-situ geoheritage. During the last decade geotourism has been enhanced in parallel with the development of Geoparks (Frey 2012; Henriques et al. 2012; Buhay and Best 2015).

Original forms of "geotourism" (late $17^{\text {th }}$ to $19^{\text {th }}$ century; Hose 2016a,b) - even if they were not called 'geotourism', the word being used only since the mid-1990s (Hose 1995) - developed mainly in natural areas (mountains and countryside) (Hose 2008; Portal 2010; Reynard et al. 2011). Urban geotourism is more recent. One of the pioneers of urban geotourism was Eric Robinson who published several geological walks in London in the 1980s (e.g. Robinson 1982, 1984, 1985). In the following years several aspects were addressed, in particular:

- the origin of building stones used in historical monuments (e.g. London, Robinson 1982; Oxford, Gomez-Heras et al. 2010; Madrid, Perez-Monserrat et al. 2013; Turin, Borghi et al. 2014, 2015; São Paulo, Del Lama et al. 2015; Balades géologiques in various cities in France, www.geosoc.fr/boutique-en-ligne , 2009-2013);

- the understanding of the geological/geomorphological features of the natural site on which a city is built (e.g. Montreal, Côté et al. 2009; Lisbon, Rodrigues et al. 2011; Rome, Del Monte et al. 2013; Pica et al. 2016b);

- the links between geoheritage and cultural heritage, in particular archaeological heritage (e.g. Mexico City, Palacio Prieto 2015; Rome, Del Monte et al. 2013); 
- the constraints of the physical environment on the urban development and vice versa the impacts of urban sprawling on geomorphological landforms (e.g. earthworks; Rome, Del Monte et al. 2016);

- urban exploitation of georesources, in particular quarries (e.g. Přikryl and Török 2010);

- urban geohazards (e.g. Lamich et al. 2016);

- geotourist mapping (e.g. Montreal, Côté et al. 2009; Rome, Pica et al. 2016b).

Urban areas also provide interesting contextual conditions for developing geotouristic products (Reynard et al. 2015): large cities and historical towns generally have a diversified offer in cultural tourism, a sector which partly attracts the same public as geotourism, i.e. visitors interested in cultural assets in a broad sense (Pralong 2006a,b); because of their location, a large number of cities have a specific natural framework (riverside cities, coastal cities, etc.) where storytelling about the interactions between human activities and natural features is easy to develop (Larwood and Prosser 1996); they benefit from modern infrastructures, in particular communication networks. The latter is particularly important for the development of digital interpretive products.

Interpretation is a central issue in the preparation of geotouristic products. Geo-interpretation is defined as "the art or science of determining and then communicating the meaning or significance of a geological or geomorphological phenomenon, event, or location" (Hose 2012). Geo-interpretation in urban contexts faces several issues. One is raising the interest of visitors for geology. It is often the aesthetic and easily readable sites that attract the non-specialists; in urban areas, buildings may hide these sites and urban sprawling may damage them. Another issue, not specific to urban contexts, is to find the good level of simplification of the scientific concepts and terminology. In fact, every geotouristic product needs a double process of codification of knowledge by the producer (in general it is the simplification of scientific results) and decodification by the users, as it is the case for example for geotouristic maps (Coratza and Regolini-Bissig 2009). In this project, we used the methodology proposed by Martin et al. (2010) for the preparation of non-personal interpretation facilities (Fig. 1). It considers four fundamental aspects and their interplay when planning a geotouristic product (being a trail, a panel, a leaflet, etc.):

- The site and objects: the geotouristic proposal must be linked with the visited site or the observed geological object; the geotouristic product is not a textbook;

- The message and content: a geotouristic product is not a list of geological elements and it should follow one main or a restricted number of specific messages that should be as coherent and concise as possible;

- The media: the scientific content is proposed to the users through various types of media (e.g. schemes, texts, multimedia tools, maps, etc.); each medium has its proper constraints that must be taken into account when preparing a geotouristic product;

- The public: geotourists are not a coherent group. The geotouristic product can be targeted to children, families, scientists, etc., and each public has its specific needs, in particular in terms of simplification of the scientific message. Moreover, the geotourism provider must take into account that geotourism is primarily a leisure activity and not an educational activity.

Fig. 1 The four fundamental aspects to consider when planning geotourist products (after Martin et al. 2010, modified).

The four variables are considered to be equivalent and interdependent (Fig. 1). Therefore, each aspect has to be carefully analysed in order to obtain a coherent product that is in line with the interests of the public and has a clearly stated communication goal (Reynard et al., 2015). In the case of mobile applications (smartphones and tablets), several issues have to be addressed (in comparison with non-digital supports such as panels, brochures or maps): 
- The sites and objects: no specific constraints relate to the links with the sites and objects to communicate on; on the contrary GPS devices included in mobile applications allow rapid positioning and, therefore, facilitate creating a link between the observer and the sites/objects;

- The message and content: the main issue is the concision, in particular if the geotourist uses a smartphone. The small size of the screen is a constraint for the elaboration of the geotouristic products; figures must be very simple and easy to read. On the other hand, interactive tools typical of virtual devices can be very useful to explain some geological features (in particular they allow a good representation of geological and geomorphological processes by showing the evolution through time or in space);

- The media: of course, digital mobile tools have specific strengths (they are easy to transport, multisensorial - the user can observe but also listen explanations -, and fun, in particular when they provide interactive material), but they have also some constraints (size of the screen, difficulty for reading the content during sunny days, connection to wireless LAN networks or Global system for mobile communication (GSM) networks, roaming costs for foreign visitors, battery charging);

- The public: not all the publics are at ease with smartphones and tablets, whereas other types of audiences, in particular teenagers, could be targeted; in some countries smartphones and tablets are less common for economic reasons what restricts the dissemination of such applications.

\section{RESULTS: MOBILE APPLICATIONS IN THREE URBAN ENVIRONMENTS}

The peculiarity of the three apps analysed in this paper is to describe urban features related to the early landscape of the city and its surroundings, allowing people to discover the anthropogenic transformations and the land use of the area. Because cultural aspects of the cities (history, monuments, urbanisation) are deeply related to the geological and geomorphological contexts, the goal of the apps is to describe the cultural landscape (Sauer 1925; Andreotti 1998; Gordon 2012) or the cultural geomorphology (Panizza and Piacente 2003) of cities, a mixture of cultural and natural heritage. The one by one descriptions below clarify how each application realizes it and how the scientific research is translated in recreational tools for non-specialist targets.

\subsection{The GeoGuide project}

The GeoGuide project (http://igd.unil.ch/geoguide) was initiated in 2013 by the Faculty of Geosciences and Environment (FGSE) of the University of Lausanne to celebrate its $10^{\text {th }}$ anniversary. The objective was to disseminate scientific knowledge - related to research projects carried out by Faculty members - to a broad audience. For this purpose a specific application - called GeoGuide was developed, and several applications for mobile devices were produced. Currently, the project proposes five applications (http://igd.unil.ch/geoguide). Three are situated in rural/mountain environments and two in urban contexts:

- GeoGuide Lausanne (2013) aims at understanding Lausanne territorial development, with a particular emphasis on the links existing between geology/geomorphology, climate and water resources, and the urban development;

- GeoGuide Hérens (2014) is focused on the geological history of an Alpine valley in the Penninic domain (Hérens valley, canton of Valais, Switzerland); 
- GeoGuide Nant (2014) presents the natural features (climate, fauna/flora, geomorphology)

- GéoDécouverte Thonon (2014) is an app developed within the context of a Master's Thesis (Fanguin 2014); it focuses on the morphogenesis of the Thonon area, in the French shore of Geneva Lake, and on the links between geomorphology, the exploitation of natural resources (in particular water) and culture;

- GeoGuide Rome (2015) was realised as a common project of Sapienza University of Rome and Lausanne University (Pica et al. 2016a); it focuses on the landscape development of Rome, with particular emphasis on the relations between geology/geomorphology, history, and legends.

All GeoGuide applications are available for devices using both Android and iOS Operating System, and as an online application as well (http://igd.unil.ch/geoguide). All the data concerning sites and attributes are organized in a single HTML file accompanied by two Javascript files with inline data and a univocal ID. Depending on the context, they are available in French or English. GPS and mobile phone networks are used for geolocation and used in an interactive map created using the Leaflet library (http://leafletjs.com) and map data is designed specifically for the GeoGuide and integrated directly into the app. Native mobile phone applications for Android and iOS are produced using Cordova and PhoneGap. This architecture provides several advantages:

- All data necessary for the GeoGuide are integrated in the app, removing the need for an Internet connection during the visit. This is especially important for foreign visitors in order to avoid potentially high roaming costs;

- A very flexible structure, allowing for adapting the GeoGuide easily to various local contexts;

- Editing the content of the app can relatively easy even by technically less experienced but trained staff;

- Inserting various contents in the GeoGuide, such as images, sounds, videos etc. is easy. Advanced interactivity and animations are possible using Javascript.

One of the drawbacks is the relatively big size of the resulting application. Consequently, the initial installation of a GeoGuide should be done over a Wireless Internet connection. Also, wrapping an HTML application inside a native application limits some development possibilities, e.g. optimization for a longer battery life.

In the following sections, we describe the apps GeoGuide Lausanne and GeoGuide Rome, which are targeted to urban geotourism, as well as a third application (TOURinSTONE) realized using the same technology as the GeoGuide apps.

\subsection{The GeoGuide Lausanne App}

With 403,000 inhabitants in 2014, Lausanne is the fifth urban agglomeration of Switzerland, after Zurich, Geneva, Basel and Bern. Tourism is mainly based on the cultural offer, in particular the presence of the Olympic Museum and the Béjart Ballet. Lausanne also benefits of the classification of the neighbouring vineyard of Lavaux as World Heritage Site since 2007.

After a first settlement developed along the Geneva Lake shore during Roman times, the medieval town moved up on the slopes on a sandstone hill isolated by two deep valleys eroded by the Flon 
and the Louve rivers. This defence site became a constraint in the $19^{\text {th }}$ century when the population increased and the city sprawled outside the medieval walls. Intense river-training works deeply modified the natural morphology, and during the $20^{\text {th }}$ century, the city went to cover all the slopes pending on Lake of Geneva.

Three types of processes influenced Lausanne's morphogenesis. During the Quaternary glaciers eroded the deep depression currently occupied by Lake of Geneva and deposited several moraines, most of them being parallel to the Geneva Lake shoreline (East-West orientation), and consequently forming obstacles for the North-South circulation. After the glacier retreat, rivers incised the glacial deposits and Molassic bedrock, forming deep valleys, which are obstacles to the East-West circulation. Finally, because of these double series of obstacles, anthropic works - in particular river training but also lakeshore planning - highly modified the original landscape. Lausanne is a city particularly interesting for understanding the close relationships existing between the natural context (climate, hydrography, geomorphology) and the urban development, as well as the impacts of urban sprawling on geomorphological features. It is for this reason that the GeoGuide Lausanne was developed.

The objective was to present to a large public research in physical and human geography carried out in Lausanne by FGSE members. Both tourists visiting Lausanne and undergraduate students in geosciences form the targeted public. An itinerary with 30 stops was organised from the north part of Lausanne (Sauvabelin forest) to the University (West of Lausanne, near Geneva Lake shore). Each stop explores one relationship between three territorial features (Table 1): Geology/Geomorphology, Water/Climate, Man/Society. The application is the result of the collaboration between the Institute of Geography and Sustainability of Lausanne University (IGD) and the private company Relief, specialized in the development of geotouristic products (Reynard et al. 2015). It was first presented in June 2013 as part of the events of the $10^{\text {th }}$ anniversary of FGSE. Some stops have also on-site interpretive facilities and others are described in an educational brochure (Theler and Reynard 2006) (see stars on Table 1 ).

\section{Table 1 here}

The design of the application, written in French, is quite simple with five pages accessible from a footer fixed toolbar (see Fig. 2):

- 'Général' is a static page containing a text informing the users on the objective and organisation of the application;

- 'Parcours' is an interactive map of Lausanne, with the itinerary and the 30 stops. The user can pan, zoom or tap one of the stops. The latter operation opens the descriptive card of the picked site. Each of these descriptive cards has the same structure, with a symbol showing which of the three spheres are concerned by the stop, a photograph and brief description of the stop surroundings, which allow rapid localization; the scientific content with appealing title (e.g. "Welcome to Lausanne-les-Bains", for stop 6, which explains former tourist use of one of the Lausanne ravines, or "Since the last glaciation, there are bananas in Lausanne" for stop 29 about moraines with banana-like shapes), one or several pictures, and a short text.

- 'Postes' is an interactive section including the list of the 30 stops (Fig. 3). Tapping an item of the list refers to the corresponding card; 
- 'Thèmes' explains the three types of relationships between the three thematic spheres;

- 'Autres' is divided in four sections. 'Aide" gives tips for the navigation. 'Infos pratiques' gives practical information for the visit (e.g. public transportation and equipment). 'Credits' acknowledges the designers of the application, and finally, the section 'Feedback' allows the users to evaluate and suggest improvements of the application.

At present a second version is being prepared, notably with two levels of information: a first level targeted to a broad public; a second level, with more scientific content for those who want to deepen their knowledge. The navigation menu moved from the bottom to the up-right corner of the screen in order to save space for the stops content.

Fig. 2 The welcome page of the GeoGuide Lausanne (left), the navigation menu (center), and the interactive map featuring the points of interest (right).

Fig. 3 The list of stops of the GeoGuide Lausanne (left), and the explanations for two of the stops (center and right).

\subsection{The TOURinSTONES App}

During the last ten years Turin (North-western Italy) has gradually changed its reputation of a purely industrial city to a city with a great tourism potential. The investments aimed at the renovation of the architectural, historical and cultural heritage yielded a remarkable increase of the number of visitors making of Turin an important tourist city both at national and international level.

On the basis of this new cultural framework, and within the PROGEO-Piemonte project (http://www.progeopiemonte.it/, Ferrero et al. 2012), the Earth Sciences Department of the University of Turin started a project aimed at the realisation of a mobile application addressed at the promotion of urban geological and petrographic heritage. The idea arose from three main considerations:

- A wide variety of stones: metamorphic, igneous, and sedimentary have been used for building, covering or adorning the churches, the buildings, the monuments and even the roads and the bridges of the city centre;

- The wealth of stone materials employed during centuries could create a connection between the history of the city and the geology of Western Alps;

- Informing the public administrations and the experts of the tourist industry could increase and enhance the tourist offers including topics usually neglected.

The application TOURinSTONES (http://www.progeopiemonte.it/multimedia/) was first released for the $22^{\text {nd }}$ Congress of the International Association of Engineering Geology (IAEG), held in Turin in September 2014, and tested later in several excursions carried out with high-school students.

Developing a dedicated application on such specific and in many ways hard subject required careful planning. Adapting the methodologies proposed by Coratza and Regolini-Bissig (2009) and Martin et al. (2010) we first identified the potential users of the application as a public of scholars with some basic Earth Sciences understanding. The purpose was to provide petrographic and geological 
information about the stones and their usage in the city of Turin, keeping the complexity of the data as low as possible.

Among the 150 varieties of stones used during different historical periods we focused the attention mainly on those outcropping or mined in the Western Alps, but without leaving out those coming from outside the region that for aesthetic and physical characters are very widespread (e.g. marbles). Overall more than 50 different stones were described, simplifying, as far as possible, the scientific literature. Among the works published and used as reference sources there are: Sacco (1907), which described the city of Turin under the point of view of the applied geology; Peretti (1937) about the structural and ornamental stones used in the first section of Via Roma; Fiora and Ferrarese (1998) about the green marble of the Aosta Valley; Fiora et al. (2000) about the usage of Syenite in urban environment; Fiora and Audagnotti (2001) about the marbles mined in the Susa Valley; Fiora et al. (2002a, 2002b) on ancient and contemporary stones of Piemonte region; Fiora and Alciati (2006) about the coloured marbles of Piemonte region; Fiora et al. (2007), who for the first time realized a multimedia petrographic guide (http://pietreditorino.com/) of the city of Turin; Borghi et al. (2009) on the withe marble used in Antiquity; Massaro (2013), who performed a petrographic study of sedimentary rocks used as stone materials in the historical architecture of the city; Borghi et al. (2014), who provided a representative list of the most important ornamental stones of Piemonte region.

On the basis of the geoscientific information, 24 sites scattered all around the city centre were selected, offering the best combination of historic, geological and petrographic values (Table 2).

\section{Table 2 here}

They can be visited singularly, without the needs to proceed along a prearranged itinerary. The application is presented in English and the design of the application is very simple with five pages accessible from a footer fixed toolbar (Fig. 4):

- 'Home' is a static page containing text and images informing the users about the aim of the application;

- 'Maps' is an interactive page of the Turin city centre, where the user can do several actions such as pan, zoom or tap one of the 24 points of interest. This latter action opens up the descriptive card of the picked site;

- 'POI' (Point of Interest) is an interactive section including the list of the 24 sites. Tapping an item of the list opens up a structured page with images of the site, brief historic information and a detailed indication of the main ornamental stones used in the construction of the building (Fig. 5 on the left). Positioned at the top of the page, a button allows the user to access a new list section containing geo-information about the stones employed in that particular site;

- 'Stones' is a section with the same features of the previous. The list view includes 53 stones characterized by different icons depending on the types of the rocks: metamorphic, marble, igneous and sedimentary rocks. Tapping an item of the list opens up a structured page with petrographic and commercial name, location of the main quarry districts, description of the macro features characterizing the stones, some notes about the geological context and the main usage of the rock (Fig. 5 in the middle). Supplied with alphanumeric information there 
are images of the external aspect of the rock and a geological sketch showing the context of the quarry district (Fig. 5 on the right).

- 'Credits' is a static page including sources of information and acknowledgement of those who participated in the project.

At present a second version, both in English and Italian, is being defined; in addition to an updated version of TOURinSTONES eight extra geo-itineraries scattered all over the region will be available.

Fig. 4 TOURinSTONES mobile application. From left to right: Home page; city center Map indicating 24 Points of Interest; List of the Points of Interest; List of the Stones.

Fig. 5 TOURinSTONES mobile application. From left to right: description and image of a Point of Interest; information about the Stones; image of the stone and geological sketch of the Western Alps with a mark representing the main quarry district.

\subsection{The GeoGuide Rome App}

Rome is known worldwide for its cultural, historical and religious heritage, which makes the city the third tourist town in Europe (after London and Paris). Geomorphology is much less known and quite poorly addressed by the tourism sector, although the geomorphological framework has conditioned the economic and cultural development of the city. This was the origin of a project on Rome urban geomorphological heritage developed by Sapienza University of Rome (Del Monte et al. 2013, 2016; Pica et al. 2016b). A geomorphological analysis of Rome was at first time carried out with the classical approach of geomorphological survey. In spite of the strong urbanization of Rome lots of geomorphological features are still recognizable. The Tiber River crosses the centre of the city, gravitational landforms affect the northwest part of the city, structural landforms are well represented in the East and fluvial landforms are present where man-made modifications are not too important. In particular many differences are evident between the west and the east side of the Tiber valley along its urban stretch. They are due to different outcropping lithologies, marine and continental on the west side, volcanic and fluvial on the east side. These differences deeply influenced the city foundation and its urbanisation during centuries. Rome arose on the east side and even now the urbanisation and the man-made transformations are deeper on this side.

A regional inventory of geosites of Lazio region was carried out by Fattori and Mancinella (2010), who selected seven geosites in the Rome area, all of them being geomorphosites. Based on the analysis of urban geomorphological heritage carried out by Sapienza University of Rome two supplementary geomorphosites - Tiberina Island and Testaccio Mount - were added to the geoheritage inventory (Del Monte et al. 2013; Pica et al. 2016b), for both scientific value and additional values (in the sense of Reynard 2005), such as historical and aesthetic.

Data management in GIS environment, following a methodology proposed by Gregori and Melelli (2005), allowed the automatic choice of geosites having high geotouristic interest by means of queries to a relational database. This led to the selection of three geosites and the creation of a geotouristic itinerary connecting these sites with 9 stops (Pica et al. 2016a,b). The first attempt to the geotourist itinerary enhancement consists of a leaflet edited by Sapienza Publishing Centre (Del Monte et al., 2014), describing stop by stop the itinerary. Any panel is put on sites, authors and local authorities are discussing about this kind of tools for heritage popularization. 
The GeoGuide Rome (http://igd.unil.ch/geoguide) is based on this previous work and is a common project of the Department of Earth Sciences of Sapienza University of Rome and the Institute of Geography and Sustainability of Lausanne University. It offers the opportunity to discover in a smart way the main geological-geomorphological characteristics of Rome in 18 stops. Eleven are organised along an itinerary from the Circus Maximus at the foot of the Palatino hill to the Gianicolo hill. They are divided by themes exploring the links between three areas of interest: GEO aspects (geology and geomorphology), HIStorical-archaeological interests and LEGends (Table 3). Seven additional points of observation allow the visitors to discover the Seven Hills where the myth of the Eternal City was born. The application was presented for the first time in April 2016 during the European Geosciences Union General Assembly (Pica et al. 2016a).

Table 3 here

The application is written in English and the contents are organized in the same way as for the GeoGuide Lausanne, proposing four educational themes (GEO, HIS, LEG, 7HILLS), an itinerary arranged in georeferenced stops shown by images and described in their characterizing aspects. At the bottom five tabs are shown: WELCOME, MAP, STOPS, THEMES, OTHER and they are repeated at the bottom of each page. The tabs are the tools to navigate in the application (Fig. 6):

- 'Welcome' is a static page containing text informing the users about the goal and the structure of the app (the itinerary and the stops) and giving instructions how to navigate;

- 'Map' is an interactive page of Rome city centre, where the user can pan, scroll and zoom to get more information. A tap on one of the 18 observation points, represented on the city map and geolocalized, allows the users to access the contents and the illustrations;

- 'Stops' is an interactive section including a list of the 11 stops of the itinerary and the Seven Hills of Rome interest points. Tapping on each small arrow on the right of the list opens up a page with images, historic information and geological-geomorphological features of the selected site. The list of stops also shows the number of the icon in the map and the themes related to each stop (Fig. 7), so that the user can choose the stop depending on his interests or his position.

- 'Themes' are Geology, History, Legends and 7Hills. By means of the relationships between them they educate the users to the links existing between geology/geomorphology and humans in a cultural geomorphology perspective (in the sense of Panizza and Piacente, 2003). In this tab the legend of themes' icons is shown and each theme described (see Fig. 6).

- 'Other' is a static page divided in four sections: 'Help' explains how to navigate: how to view and geolocalize the stops, to zoom the map or scroll the page. 'Credits' talks about developers, scientific supervisors and technical designers. 'Feedback' is requested to improve the work. 'More infos' suggests scientific papers to deepen the knowledge.

At the moment GeoGuide Rome is a tool used for educational activities for university students, but its spreading is getting wider thanks to the dedicated website (http://igd.unil.ch/geoguide), showing the web version of the app. The web version will be soon available also on the Sapienza University website and the Earth Sciences Department of Sapienza University is planning some agreements with institutions to include the application in Rome's touristic offer. 
Fig. 6 The main tabs of the GeoGuide Rome app. The navigation menu is in the lower part of each screen shot, the tab name is in blue: (from left to right) welcome page, interactive map and points of interest, description of themes.

Fig. 7 The list of stops showing the themes related to a specific point of interest: tapping on Circus Maximus the page opens up and the GEOlogical, HIStorical and LEGendary aspects of the site are described and explained.

\section{Discussion}

The scientific literature in the field of technologies for tourism is increasing, with numerous examples of mobile guides aimed at generic tourism purposes (Kenteris et al. 2011a). Mobile applications are proposed to explore and learn about a city, as guides for museum visits, to recommend interesting tours or to provide easier orientation for tourists (e.g. Düpmeier and Ruchter 2004; Haller et al. 2005; Kenteris et al. 2011b; Kounavis et al. 2012; Wang et al. 2012; Umanets et al. 2014; Sorrentino et al. 2015; Gavalas et al. 2016). The examples in literature highlight some strengths of using mobile technologies for tourism, such as navigational assistants using positioning technologies, to consult multimedia material, to listen audio descriptions and to have automatic updating of content. A limit of the tools for tourism is that most of the mobile devices are developed only for cultural tourism, expecially in urban areas, neglecting the geotourist potential.

The GeoGuide apps have both educational and recreative aims, such as the dissemination of scientific knowledge to a broad audience and the explanation of the links between natural and cultural heritage by mobile devices and interpretative contents. The project GeoGuide includes several apps enhancing geological and geomorphological aspects in natural areas, whereas the three apps described above have the specificity to be implemented in urban areas.

The tourism based on natural aspects of urban areas is a very new frontier and the examples of urban geotourism are very recent (Rodrigues et al. 2011; Del Monte et al. 2013; Del Lama et al. 2015, 2016; Dóniz-Páez and Becerra-Ramírez 2015; Poretti et al. 2015; Pica et al. 2016b). To our knowledge the Lausanne, Rome and Turin GeoGuides are the only open source geotourist applications using mobile technologies. GeoGuide apps are the perfect tool to allow the tourism sector to add geotouristic contents to the cultural offer of a city thanks to several strengths:

- The GeoGuide apps user can interact with all the elements describing the identity of the territory, its geomorphology, culture and heritage. Tourists coming in a city to see archaeological ruins or monuments use the app to read short sentences and interpretative schemes explaining land use, history and cultural aspects of the sites (e.g. Rome and the Circus Maximus stop; see Fig. 7). The goal of geotourism is to make visitors aware of these values and interactions (Arouca Declaration 2011) and the mobile technology makes it recreative and smart.

- They allow spreading the geological knowledge about a territory and its geoheritage, composed of sites but also collections of geological objects. A walk in the city looking for building stones is the occasion to appreciate the architecture of the city and to collect information about the origin of materials (e.g. Turin and Piazza San Carlo; see Fig. 5). The apps contribute to the promotion of the links between cultural and geological heritage.

- The interpretation facilities for geotourism are magnified by the digital technology of the apps and it is useful for urban geotourism because the intense anthropogenic transformations often hide the early landscape of a urban area. The overlay of images, 
sounds and video allows the visitors to discover landforms that are invisible or now covered by buildings and infrastructures (e.g. three examples in Lausanne: stratification overlay on the Flon cascade (Fig. 8a), glacier landscape in Montbenon (Fig. 8b), Lausanne and the confluence of the Flon and Louve rivers (Fig. 8c)).

- The GeoGuide apps for urban geotourism help to convey the message that substrate profoundly influences the culture that is established on it. In urban areas the link between the original shapes of the landscape, the rocks that make it up and the use and the shaping that mankind has made is particularly significant: this is evident in Lausanne, Turin and Rome examples.

Fig. 8 Three examples of pictures showing palaeolandscapes and landforms now burried by urbanization in Lausanne. a) stratification overlay on the Flon cascade; b) glacier palaeolandscape in Montbenon; c) reconstruction of the confluence of the Louve and Flon river now covered by streets (@ GeoGuide Lausanne).

GeoGuide apps have also technical strengths (see also Reynard et al. 2015):

- Accessible online, as a website, they allow users to look for additional information and to organize the city visit at home or to re-experience it after the trip;

- They are usable on any kind of device (smartphones, tablets, computers) and the stand-alone mobile app version does not require any Internet connection, making them easily accessible to anyone;

- They do not have any impact on the field, such as panels or signs on the sites for which authorisations can be difficult to obtain in urban environments;

- They are concise, easy to read, rich of didactic figures, interactive, easy to transport and playful.

GeoGuide apps power the tourist offer in urban areas thanks to the original topics proposed and the modern technology applied.

\section{Conclusions}

Urban areas have a diversified offer in cultural tourism but they are also interesting places for developing geotourism because they attract partly the same public. The natural framework of the cities allows storytelling about the interactions between human activities and natural features and the presence of very good communication infrastructures allows the development of geotourism products using smartphone and tablet technologies.

The use of good practices in the fields of natural sciences education (Giordan 1991) and heritage interpretation (Tilden 1957; Beck and Cable 2002) makes the GeoGuides aimed at a wide, nonspecialized audience, thanks to some tips - such as the use of enigmatic titles, short texts and attractive pictures (e.g. Fig. 8) - used to facilitate communication and education on rather complex and poorly known subjects (see Reynard et al. 2015 for details). This aspect relies to the objective of facilitating the decodification process by ley-people (Coratza and Regolini-Bissig, 2009) and making non-specialist people curious about what geosciences can teach or make them conscious of how man interacts with landscape, building the signs of his culture and traditions in the cities. 
The public understanding of science is very important, it helps enhancing the role of the researchers and the impact of their work on the society and the daily lives of citizens. In this context GeoGuide apps are useful to disseminate research results: how man influences the landscape evolution, modelling natural landforms and using them and the rocks to build the cities, the monuments, the roads and other elements of his culture. GeoGuide apps help transfer knowledge and make it usable to people.

\section{Acknowledgements}

The Faculty of Geosciences and Environment of the University of Lausanne is thanked for financial support provided for the technical and methodological development of the first version of the GeoGuide application. The Institute of Geography and Sustainability is thanked for providing technical support and working places for the researchers of Rome and Turin. Géraldine Regolini and Simon Martin (Relief company) are acknowledged for their participation to the methodological development of the first version of the GeoGuide Lausanne.

\section{REFERENCES}

Andreotti G (1998) Alle origini del paesaggio culturale: aspetti di filologia e genealogia del paesaggio. Unicopli, Milano

Arouca Declaration (2011) Arouca Declaration on Geotourism, November 12, 2011, http://www.europeangeoparks.org/?p=223 (accessed 15 January 2017)

Beck L, Cable T (2002) Interpretation for the 21st century. Fifteen guiding principles for interpreting nature and culture, 2nd ed. Sagamore, Champaign

Borghi A, Fiora L, Marcon C, Vaggelli G (2009) The Piedmont white marbles used in antiquity, an archaeometric distinction inferred by a minero-petrographic and C-O stable isotope study. Archaeometry 6:913-931

Borghi A, D'Atri A, Martire L, Castelli D, Costa E, Dino G, Favero Longo SE, Ferrando S, Gallo LM, Giardino M, Groppo C, Piervittori R, Rolfo F, Rossetti P, Vaggelli G (2014) Fragments of the Western Alpine chain as historic ornamental stones in Turin (Italy): enhancement of urban geological heritage through geotourism. Geoheritage 6:41-55. doi:10.1007/s12371-013-0091-7

Borghi A, Berra V, D’Atri A, Gino GA, Gallo LM, Giacobino E, Martire L, Massaro G, Vaggelli G, Bertok C, Castelli D, Costa E, Ferrando S, Groppo C, Rolfo F (2015) Stone materials used for monumental buildings in the historical centre of Turin (NW Italy): architectonical survey and petrographical characterization of Via Roma. In: Pereira D, Marker BR, Kramar S, Cooper BJ, Shouenborg BE (eds) Global heritage stone: towards international recognition of building and ornamental stones. The Geological Society, London, Special publication 407, pp 201-218

Brilha J (2005) Património geológico e geoconservação: a conservação da natureza na sua vertente geológica. Palimage Editores, Viseu

Brilha J (2016) Inventory and quantitative assessment of geosites and geodiversity sites: a review. Geoheritage 8(2):119134. doi:10.1007/s12371-014-0139-3

Buhay DN, Best LA (2015) Informal learning at Stonehammer and English Riviera Geoparks. Geoheritage 7(2):165-175

Cayla N (2014) An overview of new technologies applied to the management of geoheritage. Geoheritage 6:91-102. doi:10.1007/s12371-014-0113-0

Côté A, Joly MC, Verner A (2009) Géotourisme urbain. Le cas de Montréal. Téoros, 28(2):97-99

Coratza P, Regolini-Bissig G (2009) Methods for mapping geomorphosites. In: Reynard E, Coratza P, Regolini-Bissig G (eds). Geomorphosites. Pfeil, Munich, pp 89-103

Del Lama EA, de La Corte Bacci D, Martins L, da Glória Motta Garcia M, Kazumi Dehira L (2015) Urban geotourism and the old centre of São Paulo City, Brazil. Geoheritage 7:147-164. doi:10.1007/s12371-014-0119-7

Del Lama EA, Kazumi Dehira L, Grossi D, Kuzmickas L (2016) The colour of the granite that built the City of São Paulo, Brazil. COLOR Research and Application 41(3):241-245. doi: 10.1002/col.22018

Del Monte M, Pica A, Vergeri F, Ciccacci S (2014) Historical Rome in the Tiber River Valley. Field Trip Guidebook IAEG XII Congress, Torino, 2014. Centro stampa Università, Editrice Sapienza, Roma

Del Monte M, D’Orefice M, Luberti GM, Marini R, Pica A, Vergari F (2016) Geomorphological classification of urban landscapes: the case study of Rome (Italy), Journal of Maps 12:178-189 
Del Monte M, Fredi P, Pica A, Vergari F (2013) Geosites within Rome City center (Italy): a mixture of cultural and geomorphological heritage. Geogr Fis Din Quat 36:241-257. doi:10.4461/GFDQ.2013.36

Dóniz-Páez J, Becerra-Ramírez R (2015) Geoturismo urbano en Puerto de la Cruz (Tenerife, Canarias, España). In: Hilario A, Mendia M, Monge-Ganuzas M, Fernández E, Vegas J, Belmonte A (eds) Patrimonio geológico y geoparques, avances de un camino para todosPublicaciones del Instituto Geológico y Minero de España Serie, Cuadernos Del Museo Geominero 18

Dowling RK, Newsome D (2006) (eds) Geotourism: sustainability, impacts and management. Elsevier, Oxford

Düpmeier C, Ruchter M (2004) User interface architecture of a mobile guide for exploring the wild. In: 3rd International Workshop on "HCl in Mobile Guides" at Mobile $\mathrm{HCl}$ (Vol. 4), $6 \mathrm{p}$

Fanguin P (2014) Valorisation du géopatrimoine de la région de Thonon-les-Bains par l'élaboration d'un produit géotouristique. GéoDécouverte Thonon, une application mobile. Master's Thesis, University of Lausanne.

Fattori C, Mancinella D (2010) La conservazione del patrimonio geologico del Lazio. Materiali, modelli, esperienze. Edizioni ARP Agenzia Regionale Parchi, Roma

Ferrero E, Giardino M, Lozar F, Giordano E, Belluso E, Perotti L (2012) Geodiversity action plans for the enhancement of geoheritage in the Piemonte region (north-western Italy). Annals of Geophysics 55(3):487-495. doi:10.4401/ag-5527

Fiora L, Alciati L (2006) I marmi colorati del Piemonte. L'informatore del marmista 533:16-22

Fiora L, Alciati L, Borghi A, Callegari G, De Rossi A (2002a) Pietre piemontesi storiche e contemporanee. L'informatore del marmista 489:50-59

Fiora L., Alciati L., Costa E., Rolfo R., Sandrone R. (2002b) La Bargiolina: pietra storica piemontese. L'informatore del marmista 486:6-16

Fiora L, Audagnotti S (2001) II Marmo di Chianocco e Foresto: caratterizzazione minero-petrografica ed utilizzi. In: Atti del $1^{\circ}$ congresso nazionale di archeometria. Patron Editore, Bologna, pp 235-246

Fiora L, Carando M, Sandrone R (2007) Multimedia petrographic guide of the city of Torino, Italy. Per Miner 76:91-97

Fiora L, Ferrarese P (1998) I marmi verdi della Valle d'Aosta. L'informatore del marmista 37:6-14

Fiora L, Fornaro M, Manfredotti L (2000) Impiego della Sienite piemontese nell'arredo urbano. In: Quarry Lab Monument International Congress Proceedings, vol 1, pp 299-308

Frey ML (2012) Vulkaneifel, a role model for the European \& Global Geoparks Network. Proceedings of the Contact Forum "Geoheritage, Geoconservation \& Geotourism", Royal Flemish Academy of Belgium for Science and the Arts, pp 31-44

Gavalas D, Kasapakis V, Konstantopoulos C, Pantziou G, Vathis N (2016) Scenic route planning for tourists. Personal and Ubiquitous Computing 21(1):137-155. doi:10.1007/s00779-016-0971-3

Giordan A (1991) La modélisation dans l'enseignement et la vulgarisation des sciences. Impact: science et société 41(4):337-355

Gregori L, Melelli L (2005) Geotourism and geomorphosites: the G.I.S. solution. II Quaternario 18(1):283-290

Gomez-Heras M, Smith BJ, Viles HA (2010) Oxford stone revisited: causes and consequences of diversity in building limestone used in the historic centre of Oxford, England. In: Přikryl R, Török Á (eds) Natural stone resources for historical monuments. The Geological Society, London, Special Publications 333, pp 101-110

Gordon JE, (2012) Rediscovering a sense of wonder: Geoheritage, geotourism and cultural landscape experiences. Geoheritage 4:65-77

Gray M (2004) Geodiversity. Valuing and conserving abiotic nature. Wiley, Chichester

Haller R, Burghardt D, Weibel R (2005) WebPark-neue Wege mit mobilen Lösungen in Tourismusgebieten. Géomatique Suisse 5:242-245

Henriques MH, Tomaz C, Sá A (2012) The Arouca Geopark (Portugal) as an educational resource: A case study. Episodes 35(4):481-488

Hose TA (1995) Selling the story of Britain's stone. Environmental Interpretation 10(2):16-17

Hose TA (1996) Geotourism, or can tourists become casual rock hounds? In: Bennett MR et al (eds) Geology at your doorstep: the role of urban geology in Earth Heritage Conservation. The Geological Society, London, pp 207-228

Hose TA (2000) European geotourism - geological interpretation and geoconservation promotion for tourists. In: Barretino D, Wimbledon WP, Gallego E (eds) Geological heritage: its conservation and management. Instituto Tecnologico Geominero de Espana, Madrid, pp 127-146

Hose TA (2008) Towards a history of Geotourism: definitions, antecedents, and the future. In Burek CV, Prosser CD (eds) The history of geoconservation. The Geological Society, London, Special Publication, pp 37-60

Hose TA (2012) 3G's for modern geotourism. Geoheritage 4:7-24

Hose TA (2016a) Geotourism in Britain and Europe: Historical and modern perspectives. In Hose TA (ed) Geoheritage and Geotourism. A European perspective. The Boydell Press, Woodbridge, pp 152-171

Hose TA (2016b) Three centuries (1670-1970) of appreciating physical landscapes. In Hose TA (ed) Appreciating physical landscapes: Three hundred years of geotourism. The Geological Society, London, Special Publications 417, pp 1-22

Kenteris M, Gavalas D, Economou D (2011a) Electronic mobile guides: a survey. Personal and Ubiquitous Computing 15(1):97-111

Kenteris M, Gavalas D, Economou D (2011b) Mytilene E-guide: A multiplatform mobile application tourist guide exemplar. Multimedia Tools and Applications 54(2):241-262. doi:10.1007/s11042-010-0519-x.

Kounavis CD, Kasimati AE, Zamani ED (2012) Enhancing the tourism experience through mobile augmented reality: Challenges and prospects. International Journal of Engineering Business Management 4:1-6. doi:0.5772/51644 
Lamich D, Marschalko M, Yilmaz I, Bednářová P, Niemiec D, Durd'ák J, Kubečka K, Duda R (2016) Utilization of engineering geology in geo-tourism: few case studies of subsidence influence on historical churches in Ostrava-Karvina District (Czech Republic). Environmental Earth Sciences 75:128. doi:10.1007/s12665-015-4993-3

Larwood JG, Prosser CF (1996) The nature of the urban geological resource: an overview. In: Bennett MR et al. (eds) Geology at your doorstep: the role of urban geology in Earth Heritage Conservation. The Geological Society, London, pp 18-30

Martin S, Regolini-Bissig G, Perret A, Kozlik L (2010) Elaboration et évaluation de produits géotouristiques. Propositions méthodologiques. Téoros 29(2):55-66.

Massaro G (2013) Studio petrografico di rocce sedimentary utilizzate come materiali lapidei nell'architettura storica della città di Torino. MSc Thesis, University of Turin

Palacio-Prieto JL (2015) Geoheritage within cities: Urban geosites in Mexico City. Geoheritage 7:365-373. doi:10.1007/s12371-014-0136-6

Panizza M (2001) Geomorphosites: concepts, methods and example of geomorphological survey. Chinese Science Bulletin 46(Suppl. Bd):4-6.

Panizza M, Piacente S (2003) Geomorfologia culturale. Pitagora, Bologna

Peretti L (1937) Le pietre da costruzione e da ornamentazione nel primo tratto della nuova Via Roma in Torino. Marmi, Pietre e Graniti 15:1-15

Perez-Monserrat EM, Buergo MA, Gomes-Heras M, Muriel MJV, Gonzalez RF (2013) An urban geomonumental route focusing on the petrological and decay features of traditional building stones used in Madrid, Spain. Environmental Earth Sciences 69:1071-1084

Pica A, Grangier L, Reynard E, Kaiser C, Del Monte M (2016a) GeoguideRome, urban geotourism offer powered by mobile application technology. Geophysical Research Abstracts Vol. 18, EGU General Assembly 2016

Pica A, Vergari F, Fredi P, Del Monte M (2016b) The Aeterna Urbs geomorphological heritage (Rome, Italy). Geoheritage 8:31-42. doi:10.1007/s12371-015-0150-3.

Poretti G, Borghi A, D'Atri A, Dino GA, Fernando S, Groppo C,Martire L, Accattino E, Favero Longo SE, Piervittori R, Rolfo F (2015) The stone bridges on the Po River at Turin (NW Italy): a scientific dissemination approach for the development of urban geological heritage. In: Lollino $G$ et al (eds) Engineering geology for society and territory, vol. 8. Springer, Heidelberg, pp 207-211. doi:10.1007/978-3-319-09408-3_46

Portal C (2010) Reliefs et patrimoine géomorphologique. Applications aux parcs naturels de la façade atlantique européenne. PhD Thesis, University of Nantes

Pralong JP (2006a) Géotourisme et utilisation de sites naturels d'intérêt pour les sciences de la Terre. Les régions de CransMontana-Sierre (Valais, Alpes suisses) et Chamonix-Mont-Blanc (Haute-Savoie, Alpes françaises). PhD Thesis, University of Lausanne. Available at https://doc.rero.ch/record/6171/files/These_PralongJP.pdf, accessed 17 August 2016.

Pralong JP (2006) Geotourism: A new form of tourism utilising natural landscapes and based on imagination and emotion. Tourism Review 61(3):20-25. doi:10.1108/eb058476

Přikryl R, Török Á (2010) (eds) Natural stone resources for historical monuments. The Geological Society, London, Special Publication 333.

Reynard E (2005) Géomorphosites et paysages. Géomorphologie: relief, processus, environnement 3:181-188

Reynard E, Coratza P (2013) Scientific research on geomorphosites. A review of the activities of the IAG working group on geomorphosites over the last twelve years. Geografia Fisica e Dinamica Quaternaria 36:159-168

Reynard E, Coratza P, Regolini-Bissig G (2009) (eds) Geomorphosites. Pfeil, Munich

Reynard E, Hobléa F, Cayla N, Gauchon C (2011) Iconic sites for Alpine geology and geomorphology. Rediscovering heritage? Revue de géographie alpine 99(2) [on-line]. http://rga.revues.org/index1435.html (accessed 15 January 2017).

Reynard E, Kaiser C, Martin S, Regolini G (2015) An application for Geosciences communication by smartphones and tablets. In: Lollino $\mathrm{G}$ et al. (eds) Engineering Geology for Society and Territory, Volume 8. Springer, Heidelberg, pp 265-268. doi:10.1007/978-3-319-09408-3_46

Rodrigues ML, Machado CR, Freire E (2011) Geotourism routes in urban areas: a preliminary approach to the Lisbon geoheritage survey. GeoJournal of Tourism and Geosites 8(2):281-294. Available at: http://gtg.webhost.uoradea.ro/PDF/GTG-2-2011/12_100_Rodrigues.pdf. Accessed 17 August 2016.

Robinson E (1982) A geological walk around the City of London-royal exchange to Aldgate. Proceedings of the Geologists' Association 93:225-246.

Robinson E (1984) London: illustrated geological walks. Scottish Academic Press, vol. 1

Robinson E (1985) London: illustrated geological walks. Scottish Academic Press, vol. 2

Sauer CO (1925) The morphology of landscape. University of California, Publications in Geography 2:19-53

Sacco F (1907) Geologia applicata della città di Torino. Giornale Geologia Pratica 5:121-162

Sorrentino F, Spano LD, Scateni R (2015) SuperAvatar Children and mobile tourist guides become friends using superpowered avatars. In: Proceedings of 2015 International Conference on Interactive Mobile Communication Technologies and Learning (IMCL), pp 222-226

Theler D, Reynard E (2006) L'eau en ville: Lausanne. Atlas hydrologique de la Suisse, Berne (Excursions hydrologiques en Suisse 3.1)

Tilden F (1957) Interpreting our heritage. Principles and practices for visitor services in parks, museums, and historic places. University of North Carolina Press, Chapel Hill 
Various Authors (2009-2013) Collection Balades géologiques en ville. http://www.geosoc.fr/boutique-en-ligne/collectionbalades-geologiques.html, visited April 2017.

Umanets A, Ferreira A, Leite N (2014) GuideMe - A tourist guide with a recommender system and social interaction. In: Proceedings of the Conference on Electronics, Telecommunications and Computers 2013. Procedia Technology 17:407414. doi:10.1016/j.protcy.2014.10.248

Wang D, Park S, Fesenmaier DR (2012) The role of smartphones in mediating the touristic experience. Journal of Travel Research 51(4):371-387

Wimbledon WA (2011) Geosites - a mechanism for protection, integrating national and international valuation of heritage sites. Geologia dell'Ambiente Suppl Bd 2:13-25 


\section{GeoGuide Lausanne}

\section{GEO-SCIENCES THEME}

andscape

\begin{tabular}{|c|c|c|c|}
\hline 1 & Tour de Sauvabelin ** & landscape & \\
\hline 2 & Lac de Sauvabelin & antropogenic landform & history \\
\hline 3 & Cascade du Flon ** & stratigraphy & \\
\hline 4 & Dérivation du Flon ** & hydrology & water management \\
\hline 5 & Paroi de Molasse & paleo-landscape & \\
\hline 6 & Place du Vallon ** & geomorphology & history \\
\hline 7 & Tunnel de la Barre & geomorphology & history, urban planing \\
\hline 8 & Place de la Cathédrale & geology & history \\
\hline 9 & Place de la Riponne ${ }^{* *}$ & geomorphology & history \\
\hline 10 & Louve souterraine $* / * *$ & hydrology & history \\
\hline 11 & Place St-Laurent & glaciology, geomorphology & actuality \\
\hline 12 & Place Pépinet & paleo-landscape, hydrology & \\
\hline 13 & Passerelle du Flon, millieu ** & geomorphology & urban planing \\
\hline 14 & Passerelle du Flon, sud ${ }^{* *}$ & geomorphology & urban planing \\
\hline 15 & Esplanade de Montbenon ** & paleo-landscape, glaciology & \\
\hline 16 & Pont Chauderon & geohistory & history \\
\hline 17 & Avenue de Provence & air quality & mobility \\
\hline 18 & Chemin de l'Usine à Gaz & urban planning & history \\
\hline 19 & Chemin de la Prairie & urban planning & \\
\hline 20 & Vallée de la Jeunesse & geomorphology & \\
\hline 21 & Déversoir d'orage & hydrology & water management \\
\hline 22 & Giratoire Maladière & urban planning & mobility \\
\hline 23 & Stade Pierre de Coubertin & antropogenic landforms & history, urban planing \\
\hline 24 & Ruines de Vidy & paleo-landscape & history \\
\hline 25 & Siège du $\mathrm{ClO}$ & hydrology & water management \\
\hline
\end{tabular}

OTHER INTERESTS 


\begin{tabular}{llcc}
\hline 26 & STEP de Vidy & water quality & water management \\
\hline 27 & Chamberonne & water quality & \\
\hline 28 & Allée de Dorigny & geomorphology & \\
\hline 29 & Moraine de Dorigny & glaciology & architecture \\
\hline 30 & UNIL - Mouline & geoscientific research & university building \\
\hline
\end{tabular}

*Stops with on-site interpretive facilities; ** stops described in the brochure "L'eau en ville: Lausanne" (Theler and Reynard 2006). 


\section{TOURINSTONES}

\section{GEO-SCIENCES THEME}

OTHER INTERESTS

\begin{tabular}{|c|c|c|c|}
\hline 1 & Porta Nuova Railway Station & Petrography & HIS \\
\hline 2 & Via Roma (Piazza Carlo Felice - Piazza C.L.N. section) & Petrography & HIS, UP \\
\hline 3 & Piazza C.L.N. & Petrography & HIS \\
\hline 4 & Piazza San Carlo & Petrography & HIS, CUL \\
\hline 5 & Via Roma (Piazza san Carlo - Piazza Castello section) & Petrography & HIS, UP \\
\hline 6 & Town Hall & Petrography & HIS \\
\hline 7 & Mauriziana Basilica & Petrography & HIS, REL \\
\hline 8 & San Giovanni Battista Cathedral & Petrography & HIS, REL \\
\hline 9 & Palazzo Reale & Petrography & HIS, CUL \\
\hline 10 & San Lorenzo Church & Petrography & HIS, REL \\
\hline 11 & Palazzo Madama & Petrography & HIS, CUL \\
\hline 12 & Galleria Subalpina & Petrography & HIS \\
\hline 13 & Palazzo Carignano & Petrography & HIS, CUL \\
\hline 14 & San Filippo Neri Church & Petrography & HIS, REL \\
\hline 15 & Natural Sciences Museum & Petrography & HIS, CUL \\
\hline 16 & San Massimo Church & Petrography & HIS, REL \\
\hline 17 & King Umberto I Bridge & Petrography & HIS \\
\hline 18 & King Vittorio Emanuele I Bridge & Petrography & HIS \\
\hline 19 & Gran Madre Church & Petrography & HIS, REL \\
\hline 20 & Santa Annunziata Church & Petrography & HIS, REL \\
\hline 21 & Palazzo Nuovo & Petrography & HIS, CUL \\
\hline 22 & Mole Antonelliana & Petrography & HIS, CUL \\
\hline 23 & Palazzo del Rettorato & Petrography & HIS, CUL \\
\hline 24 & Regio Theatre & Petrography & HIS, CUL \\
\hline
\end{tabular}


GeoGuide Rome

STOP N

STOPS LOCATION

GEO-SCIENCES THEME

OTHER INTERESTS

\begin{tabular}{clcc}
1 & Circus Maximus & geomorphology & HIS, LEG \\
\hline 2 & Tarpeian Rock geosite & stratigraphy, geomorphology & LEG \\
\hline 3 & Capitolino & paleo-landscape & HIS, 7H \\
\hline 4 & Mount Savello & geomorphology & HIS, 7H \\
\hline 5 & Forum Boarium & paleo-landscape & HIS, LEG \\
\hline 6 & Ponte Rotto & geomorphology & HIS \\
\hline 7 & Tiberina Island geomorphosite & geomorphology & LEG \\
\hline 8 & Trastevere & paleo-landscape & HIS \\
\hline 9 & S. Pietro in Montorio & stratigraphy & HIS \\
\hline 10 & Gianicolo Fountain & idrology & HIS \\
\hline 11 & Gianicolo Balcony & landscape & HIS \\
\hline 12 & Aventino & paleo-landscape & $7 \mathrm{H}$ \\
\hline 13 & Palatino & paleo-landscape & $7 \mathrm{H}$ \\
\hline 14 & Celio & paleo-landscape & $7 \mathrm{H}$ \\
\hline 15 & Esquilino & paleo-landscape & $7 \mathrm{H}$ \\
\hline 16 & Viminale & paleo-landscape & $7 \mathrm{H}$ \\
\hline 17 & Quirinale & paleo-landscape & $7 \mathrm{H}$ \\
\hline 18 & Testaccio & geomorphology & $\mathrm{HIS}$ \\
\hline
\end{tabular}

HIS= historical value 


\section{Site}

Objects

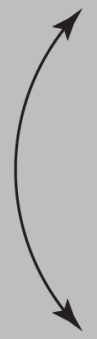

Public

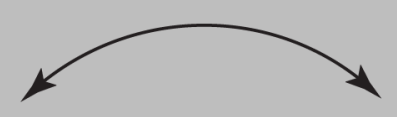

Content

Message

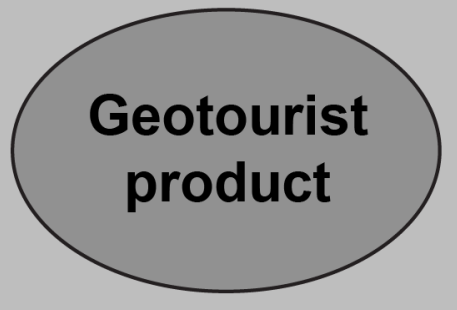

Media 


\section{Partez à la (re)découverte de Lausanne avec votre GéoGuide!}

La Faculte des gebociences et de Femviomemert de rUmorshe de Lausane partage ses suivis de recherche of vous

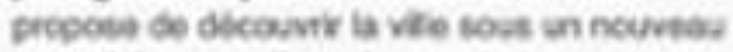
reoard: Les quariers changert ef te Qbvelospenk, les nivenes disorves rotone surtesen, le glacier au fonone fait pousuer des bevares. les tefs de Lassavne se tourent dans faau do Leman.

Partez a la recherche dos poutos qui so cachert be kng ou parcours entre Seavabelin th te cambus de rUNLL. Les 30 posies aubes ratent de nonerevor sujets.

Wous pouvez vous rende a la carte pour correble ia localisation des poetes et wubre ainsi nimolnairs.

\section{Aller a la carte :}

Wous trourtrez plus de datals graboues at une

\begin{tabular}{|c|c|}
\hline$\Theta$ Newa & A \\
\hline arte de & 6 \\
\hline & Novises \\
\hline $\begin{array}{l}\text { Wuarne } \\
\text { hous }\end{array}$ & nomen \\
\hline $\begin{array}{l}\text { fifont } \\
\text { haser des } \\
\text { rowent }\end{array}$ & $\mathrm{C}_{\text {inen }}$ \\
\hline $\begin{array}{l}\text { ye } \\
\text { puvabeln } \\
\text { nu nustis }\end{array}$ & \\
\hline pou & \\
\hline yoligeture & \\
\hline
\end{tabular}




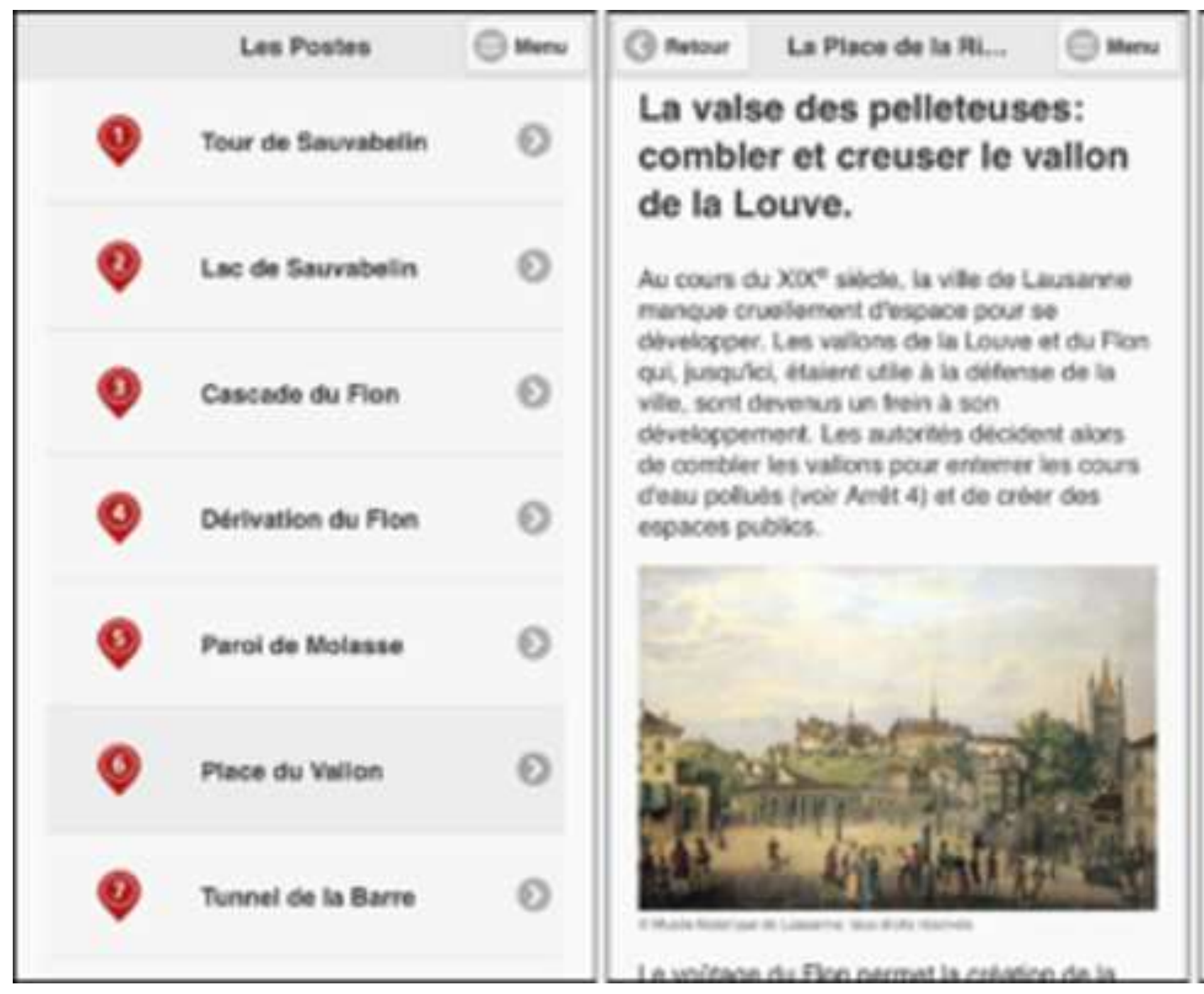

\begin{tabular}{|c|c|}
\hline (9) noweve & La Passeretle du- $\bigcirc \mathrm{Mms}$ \\
\hline $\begin{array}{l}\text { une rot } \\
\text { comme } \\
\text { rivières } \\
\text { y a } 25 \text { 'C }\end{array}$ & $\begin{array}{l}\text { te nous rappelle } \\
\text { nt le cours des } \\
\text { a été bouleversé... il } \\
00 \text { ans. }\end{array}$ \\
\hline
\end{tabular}

Le Ficn, cacte en scus-tod, descend la nive Certrale, passe sous le Grind Port et arme we la place de ITurope. La roste prindode tut lout le beg le tact da equrs dreau. Mas que se passo-4an daste apris los arches ai port. la route (et le Fon en decosus dete) lourne brsipuement mart do cortinser tout dot a vavers le quatter du fron saurea wous explaver ce chargement de drecbon?

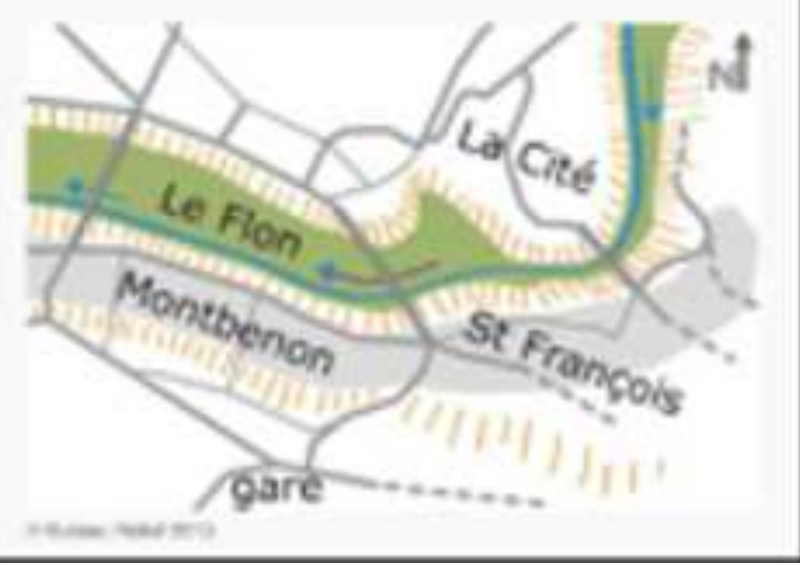




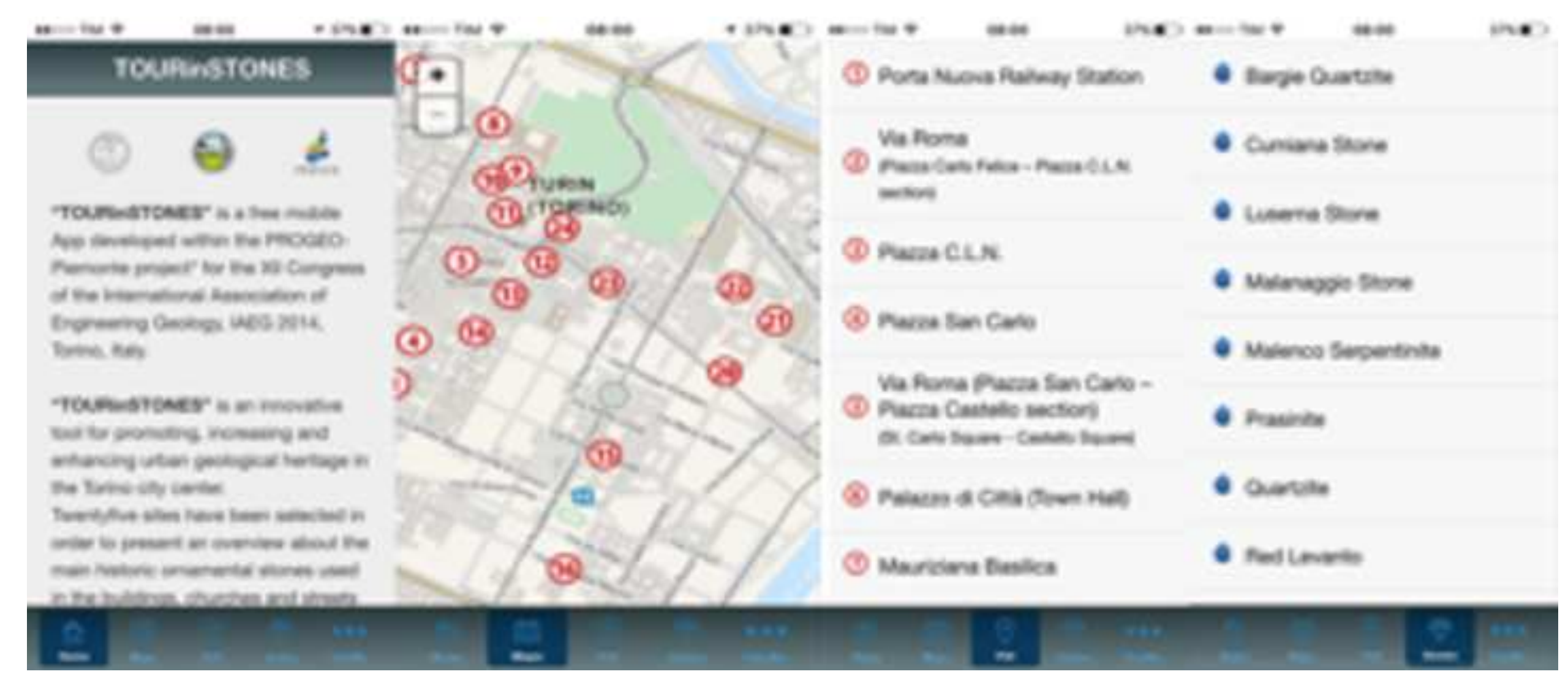




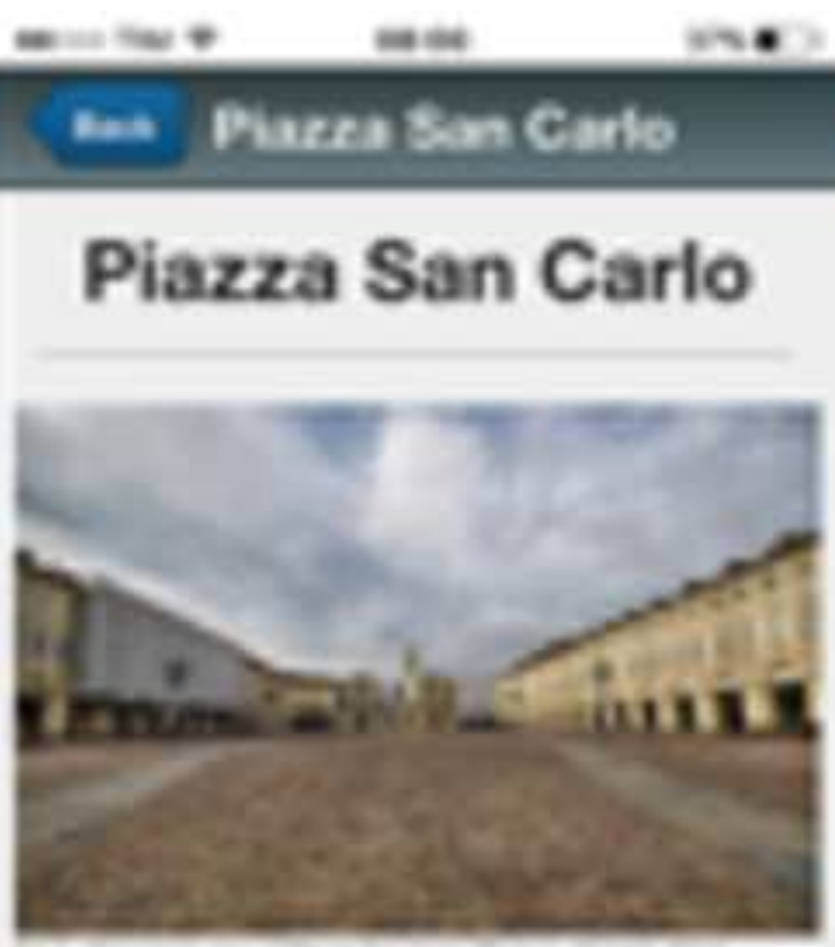

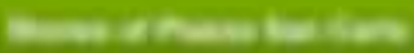

Rerse len Cas bus 4 a one of the

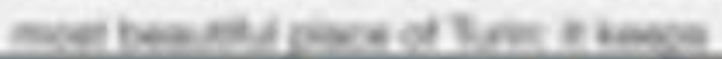

\section{Luserna Stone}

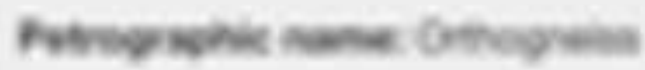

Consenie name Lueme ibon Begros nome Nos nore

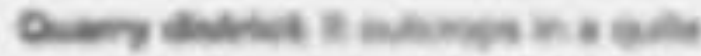

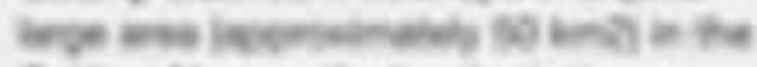

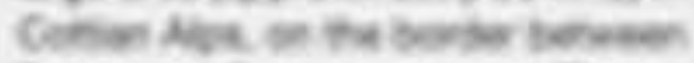

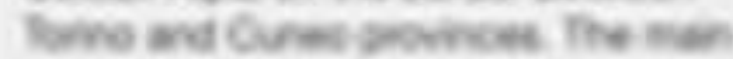

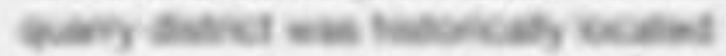

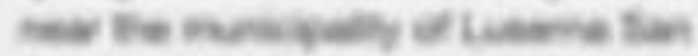

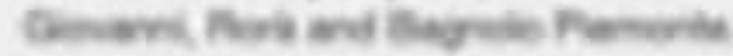

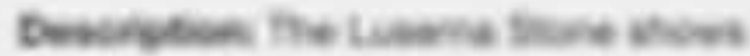

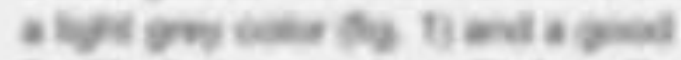

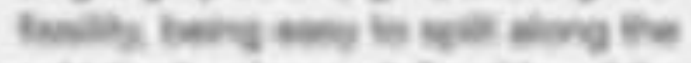

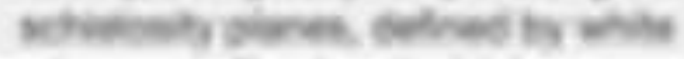
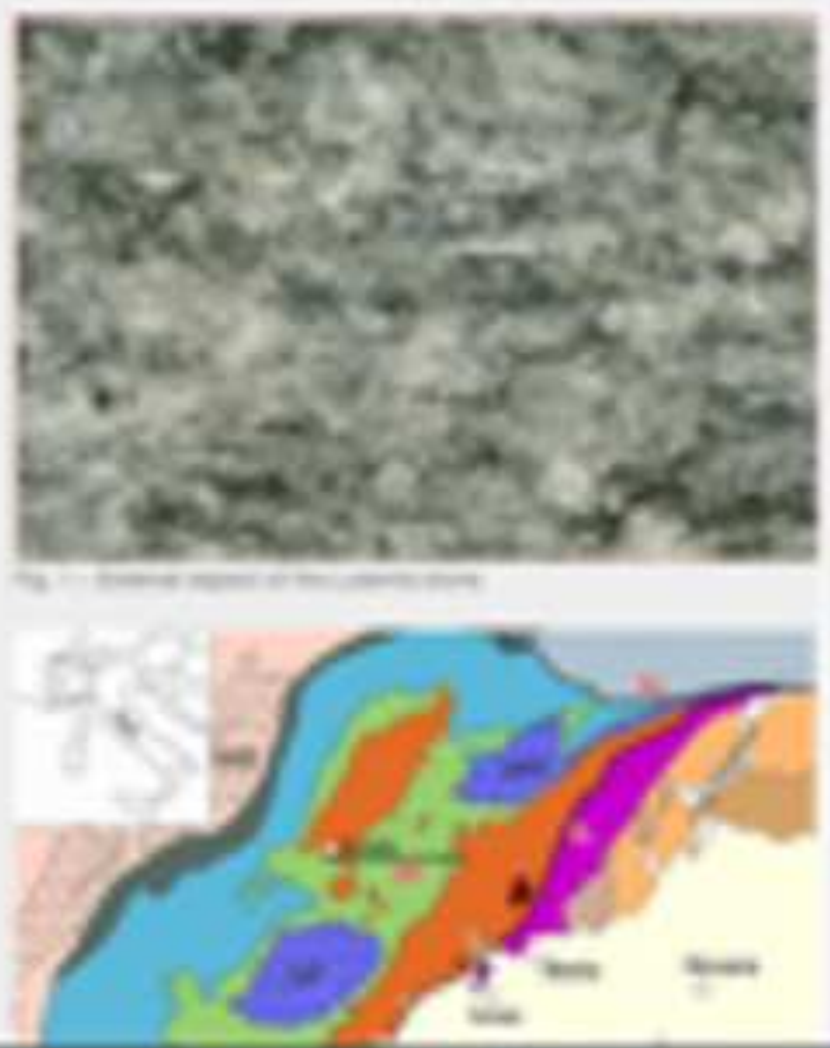


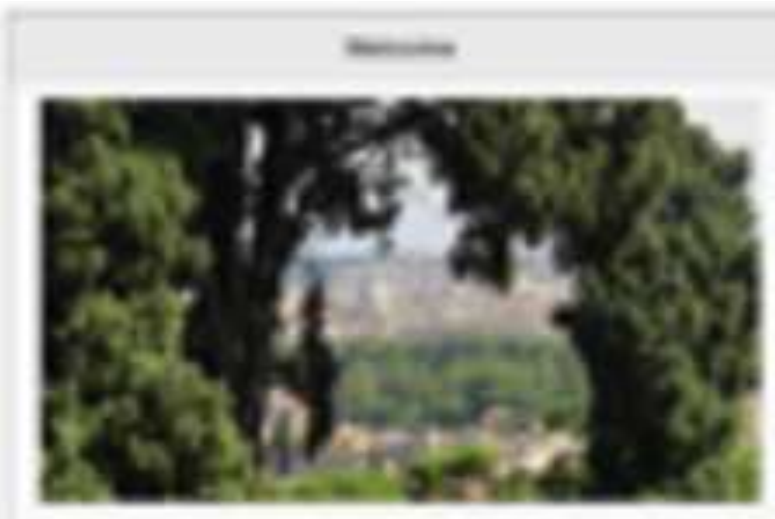

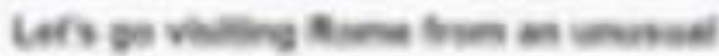

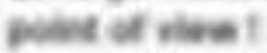

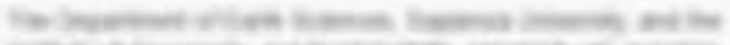

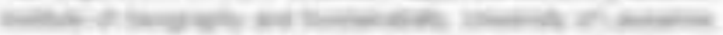

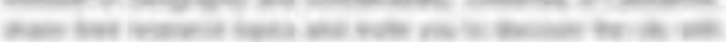

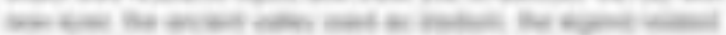

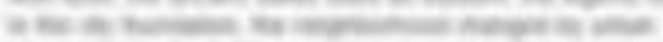

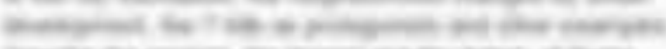

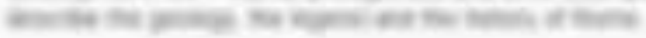

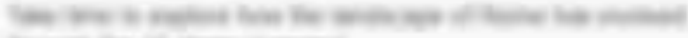

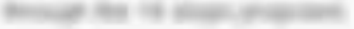

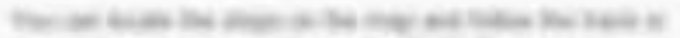

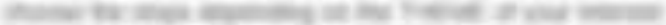
a

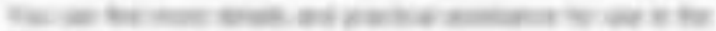

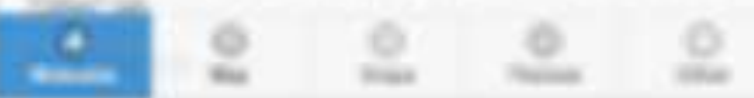
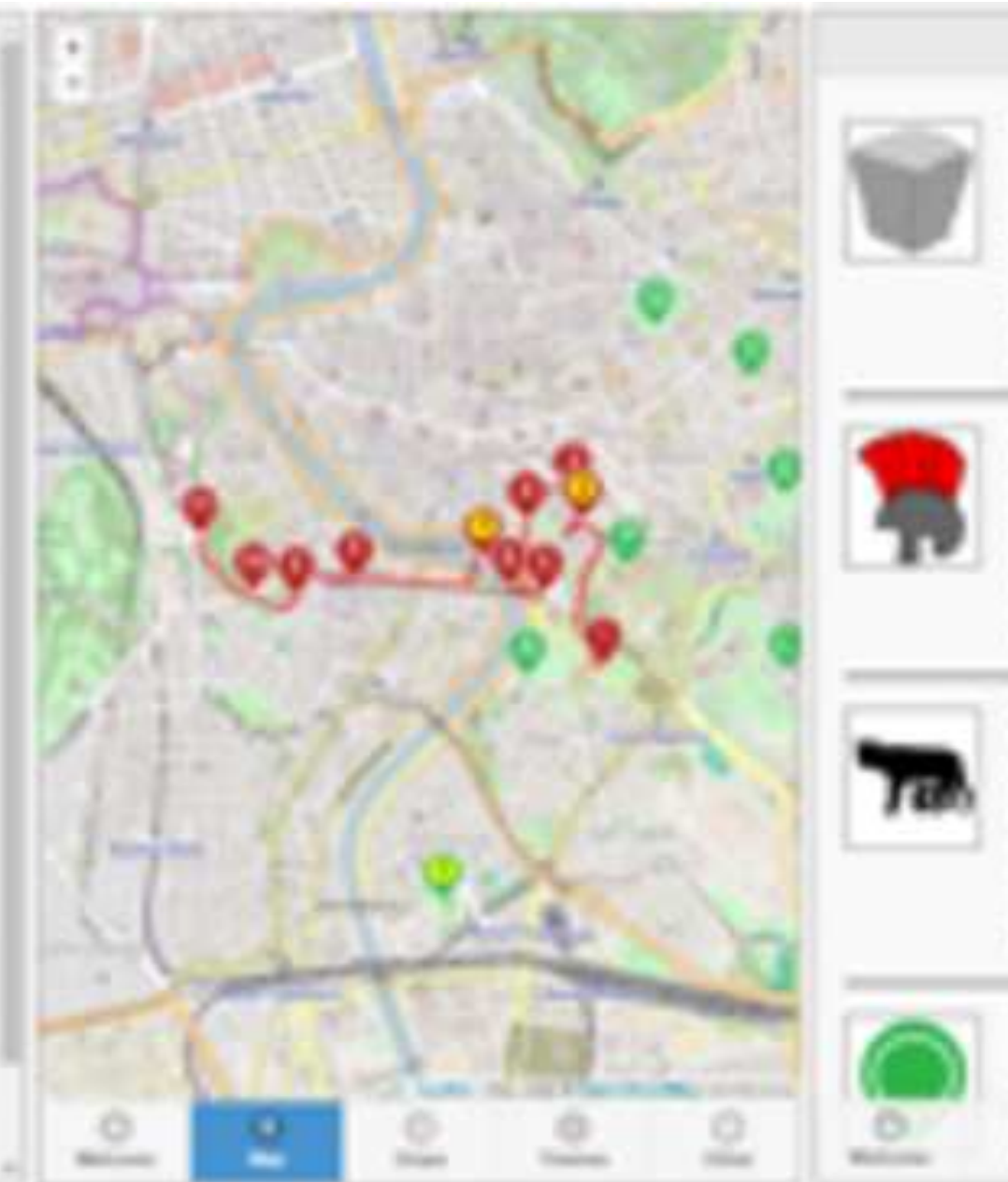

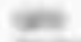

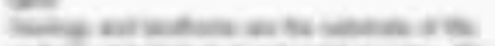
-

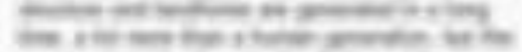
in

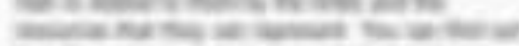
-

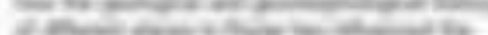
$-2+1-$

won $=$

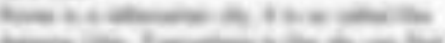

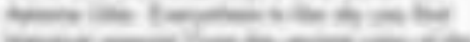

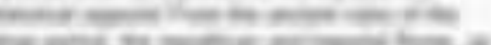

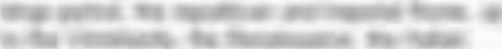

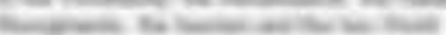

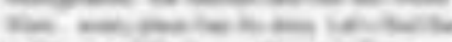

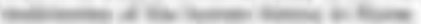

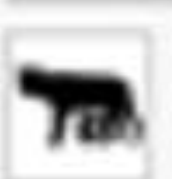

$\ln =$

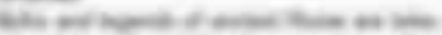

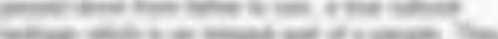

Ce

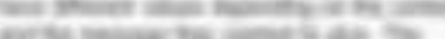

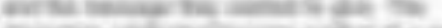

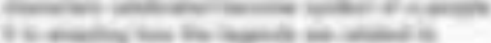

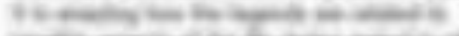

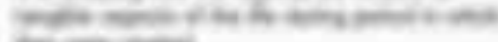

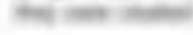

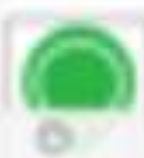

Nast

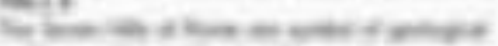

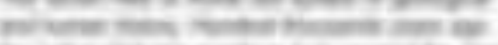

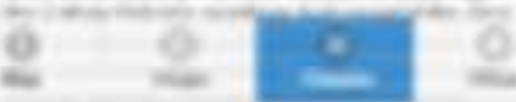




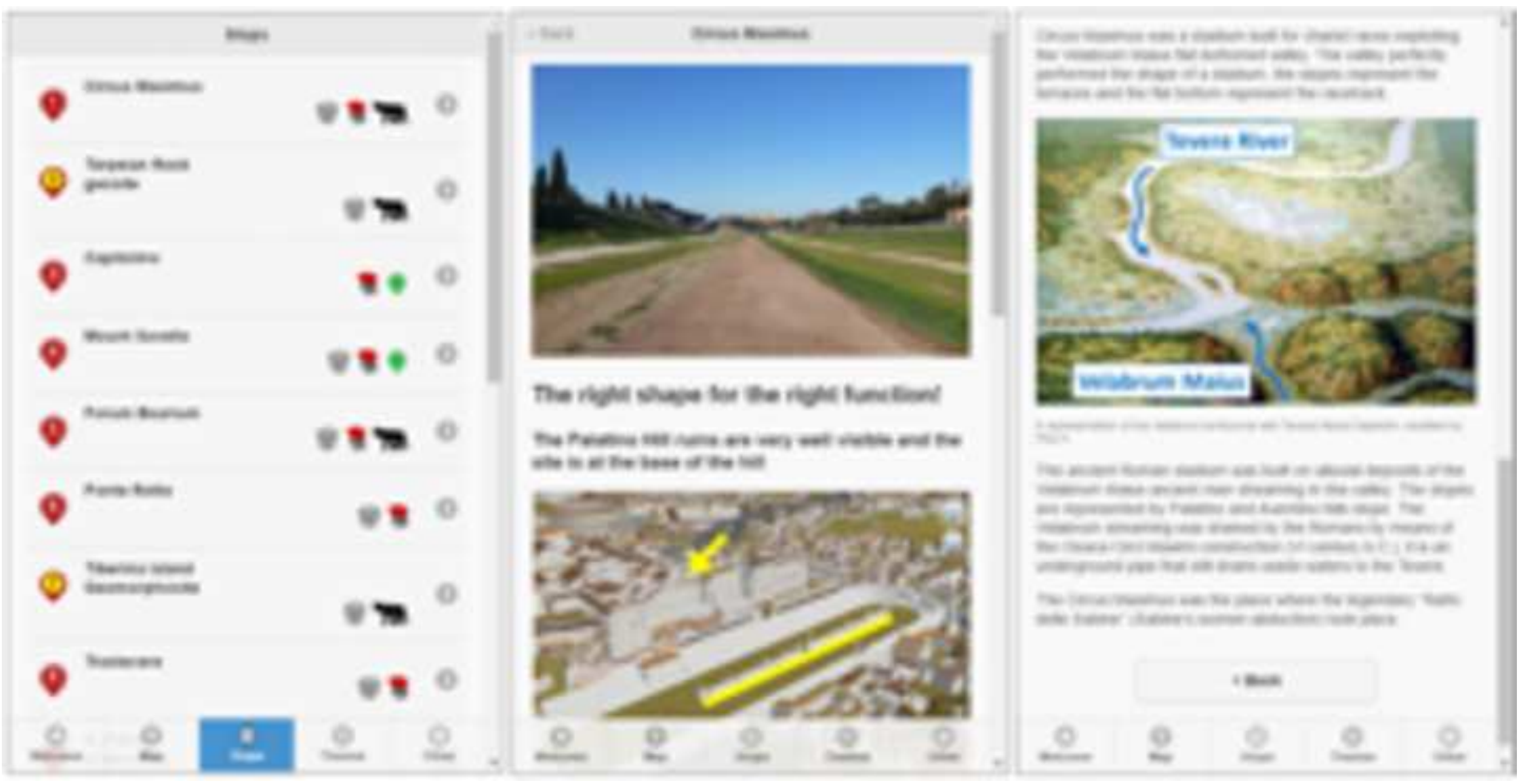

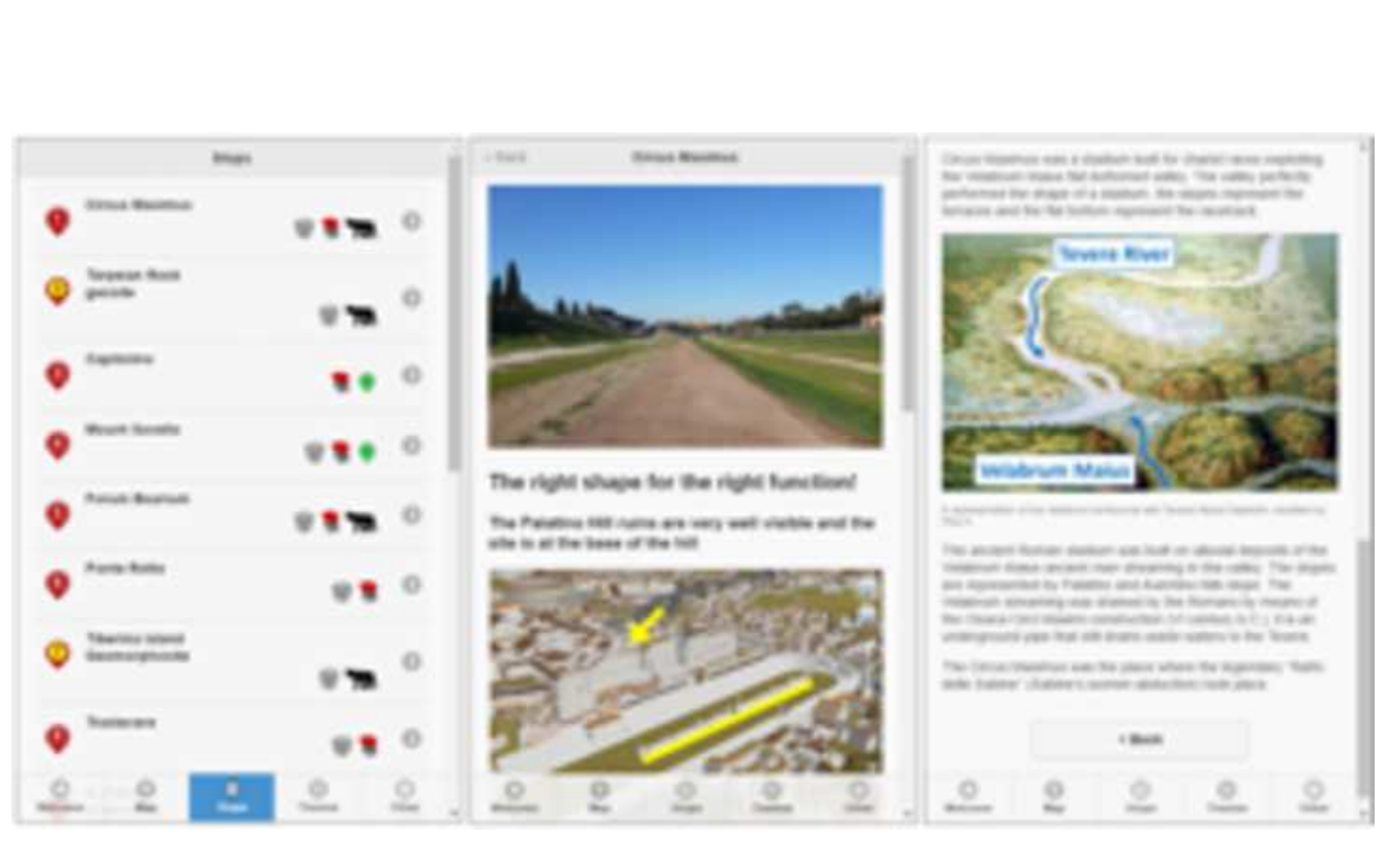
(1)

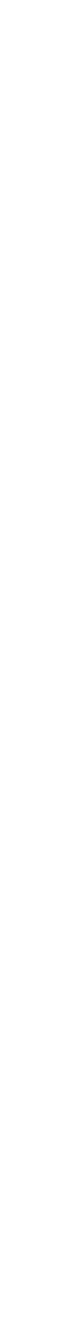
(⿸丆口 (1) e .

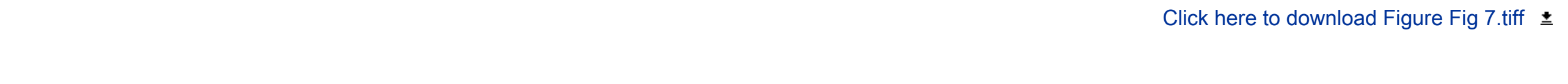

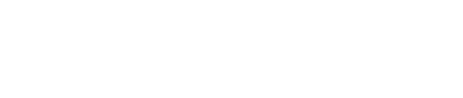

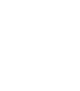

to



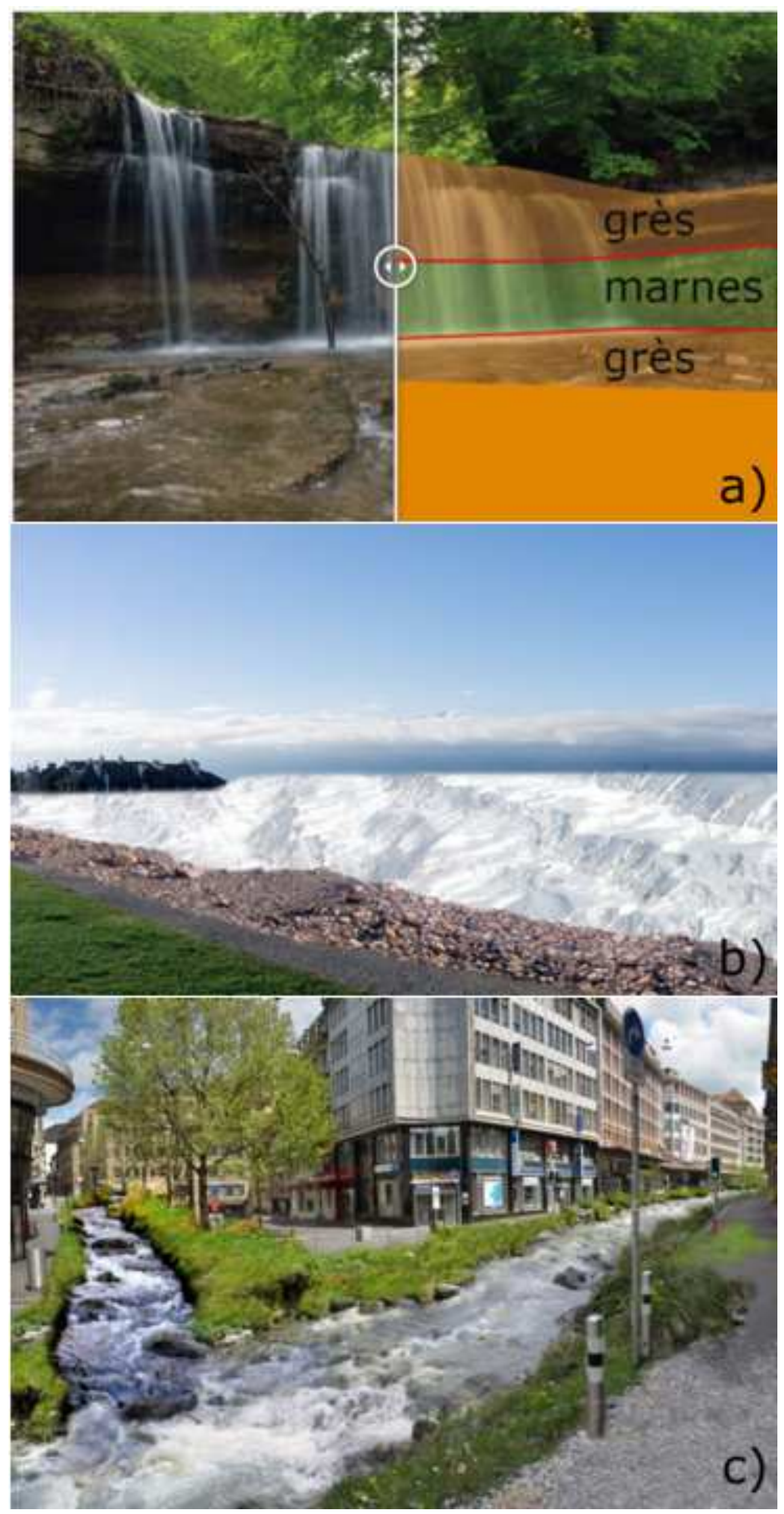